\title{
Evaluation of English 'Pediatric Basic Life Support' and 'Pediatric Cardiopulmonary Resuscitation' Videos in YouTube
}

\section{YouTube Kaynaklı İngilizce 'Pediatrik Temel Yaşam Desteği' ve 'Pediatrik Kalp Masajı' Videolarının Değerlendirilmesi}

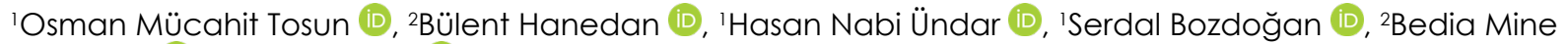 \\ Hanedan (D), ${ }^{2}$ Mustafa Atçı
}

IKonya Numune Hastanesi. Ferhuniye Mah. Hastane Cd. No:22, 42060 Selçuklu/KONYA

${ }^{2}$ Konya Şehir Hastanesi. Anesteziyoloj ve Reanimasyon Kliniği. Akabe Mah. Adana Cevre Yolu Cad. No:135 42020 Karatay / KONYA.

Correspondence

Osman Mücahit Tosun, Konya Numune Hastanesi. Ferhuniye Mah. Hastane Cd. No:22, 42060 Selçuklu/KONYA

E-Mail: osman.mucahid@gmail.com

\section{How to cite?}

Tosun OM, Hanedan B, Tutar HN, Bozdoğan S, Hanedan BM, Atç M. Evaluation of English 'Pediatric Basic Life Support' and 'Pediatric Cardiopulmonary Resuscitation Videos in YouTube. Genel Tip Derg. 2022;32(1):49-54.

\begin{abstract}
Aim: Pediatric Basic Life Support is the initiation of cardiopulmonary resuscitation (CPR) until advanced life support is available. The American Heart Association (AHA) 2015 guideline recommends the people to perform CPR.

YouTube is a video sharing site where internet users can learn about many topics, including health. Everyone can upload videos easily. Therefore, there is no control mechanism for the accuracy and up-to-dateness of the videos. Thus, there is a risk of spreading incorrect or inaccurate information. After the pediatric CPR and BLS guidelines were updated in 2015, we aimed to evaluate the quality and content of the videos published in English on YouTube.

Materials and Methods: The YouTube website was searched on 15th June, 2020, using the terms "pediatric cardiac massage" and "pediatric BLS". A total of 200 videos were evaluated by three anesthetists in terms of instructional, content, up-to dateness and resource.

Results: 33 videos included in the study were evaluated according to Azer SA criteria. 14 videos were found to be useful and 19 of them as misleading. The average total viewing times and daily viewing counts of useful videos were found to be higher. When evaluated in terms of content, similar results were obtained in both groups.

Conclusion: This research shows that viewers value videos more being educational than content. For this reason, we think that while editing videos, Azer criteria should be taken into account as an objective criterion and their content should be prepared according to current guidelines.

Keywords: basic cardiac life support, cardiopulmonary resuscitation, CPR
\end{abstract}

Öz

Amaç: Pediyatrik Temel Yaşam Desteği (TYD), ileri yaşam desteği sağlanana kadar kardiyopulmoner resüsitasyonun (CPR) bașlatılmasıdır. Amerikan Kalp Derneği (AHA)'nın 2015 kılavuzU, normal halkın kalp masajı yapmasını teşvik etmektedir.

YouTube, herkesin video yükleyebildiği veya izleyebildiği; videoların doğruluk ve güncelliği konusunda kontrol mekanizması olmayan, sağlık dahil pek çok konuda bilgi edinilebilen bir sitedir. Pediyatrik CPR ve TYD kılavuzunun 2015 yılında güncellenmesi sonucu, yeni bilgiler ısı̆ğında çalısma yapılması intiyacı doğmustur. Bu sebeple, AHA 2015 pediyatrik CPR ve BLS kılavuzu sonrası İngilizce olarak yayınlanan YouTube videolarının kalite ve içeriğini değerlendirmeyi amaçladık.

Materyal ve Metod: YouTube internet sitesine 15 Haziran 2020'de "pediatric basic life support" ve "pediatric cardiac massage" yazılarak, toplam 200 video incelendi. Videolar, eğiticilik, içerik güncellik ve kaynak açısından iki anestezist tarafından değerlendirildi.

Bulgular: Calışmaya dahil edilen 33 video Azer SA kriterlerine göre değerlendirilerek; 14'ü eğitici olmak bakımından faydalı, 19 'U ise yanıltıcı olarak bulundu. Faydalı videoların, yanıltıcı olan videolara göre; ortalama toplam izlenme süreleri, günlük izlenme sayıları daha yüksek tespit edildi. İçerik açısından değerlendirildiğinde her iki grupta da benzer sonuçlar elde edildi.

Sonuç: Bu durum izleyicilerin içerikten ziyade videoların eğitici olmasına daha fazla değer verdiğini göstermektedir. Bu sebeple videolar düzenlenirken hem objektif kriter olarak Azer kriterlerinin göz önünde olması, hem de içeriklerinin güncel kılavuzlara göre hazırlanması gerektiğini düşünmekteyiz.

Anahtar kelimeler: temel kalp yaşam desteği, kardiyopulmoner resüsitasyon, CPR

\section{Introduction}

YouTube is a social networking site that has become and professional problems occur due to misinformation extremely popular in recent years. Both medical on Youtube caused by lack of control mechanisms(2, professionals and the ordinary people can access 3). Not only medical students and other healthcare information on medical issues on Youtube. Anyone students, but also the lay public use the Internet to registered on YouTube can upload videos to the obtain health-related information. Studies conducted in platform. Uploaded videos do not undergo any the USA have shown that $4.5 \%$ of all internet searches quality control procedure(1). Despite the ease of are related to health(4). access to information, severe legal, moral, personal 
Cardiac arrest is a serious medical emergency and immediate intervention can greatly increase the victim's chance of survival. Pediatric Basic Life Support (BLS) is a systemic approach including evaluation of patients, contacting emergency medical services, and initiation of cardiopulmonary resuscitation (CPR) in pediatric patients until advanced life support is provided $(5,6)$. Initiation of CPR as soon as possible increases the chance of survival by 2-3 times(7). A study conducted in the US reported that it is common for the American public to train themselves in CPR by watching videos online (8).

There are limited studies investigating the validity of YouTube videos on CPR and BLS. The majority of existing studies focus on adult CPR videos(9-11). A previous study was conducted on pediatric CPR and BLS based on the 2010 guideline(12). However, these guidelines are updated every five years by a team of experts after reviewing clinical and experimental data and new literature evidence. The aim of the present research is to examine whether English YouTube videos on pediatric CPR and BLS prepared according to the 2015 AHA guideline are consistent with the new guidelines, provide accurate information, and whether they are educationally useful or misleading.

\section{Materials and Methods}

"Pediatric basic life support" and "pediatric cardiac massage" keywords were searched on YouTube (https://www.youtube.com; YouTube, LLC, San Bruno; CA; USA) on June 15, 2020. Videos uploaded after the 2015 AHA guideline was published were examined by two independent anesthesiologists. In case of a difference of opinion, a third anesthetist was consulted to reach a consensus.

Top 100 videos listed on the first 5 pages for each keyword were included in the evaluation(Figure 1). The reason why only the first five pages was included in the research was that later pages mostly contain unrelated videos and previous studies have shown that viewers most often watch videos on the first couple of page $(9,13)$.

\section{Exclusion criteria}

- Uploaded before 2015 ,

- Irrelevant,

- Containing advertisements,

- Without any performance, sound or practical application,

- Uploaded for academic purposes,

- Videos in a language other than English,

- Adult BLS or CPR videos,

- Repeated videos.

\section{Assessment of videos}

Assessment of the videos in terms of educational characteristics was performed by a modified methodology following the criteria published by Azer SA. As shown in Table 1, five major and six minor criteria were determined to evaluate the accuracy of the content, the clarity of the message, the presence of expert opinions on the subject, informativeness of the video, and technical design. Two points were given for each of the major criteria and one point was given for each of the minor criteria. With the condition that all the major criteria must be met, videos with a total score of 13 or more points were categorized as useful. These criteria have been successfully used in many previous studies $(1,14,15)$.

Figure 1. Consort Diagram of the YouTube videos in the study.
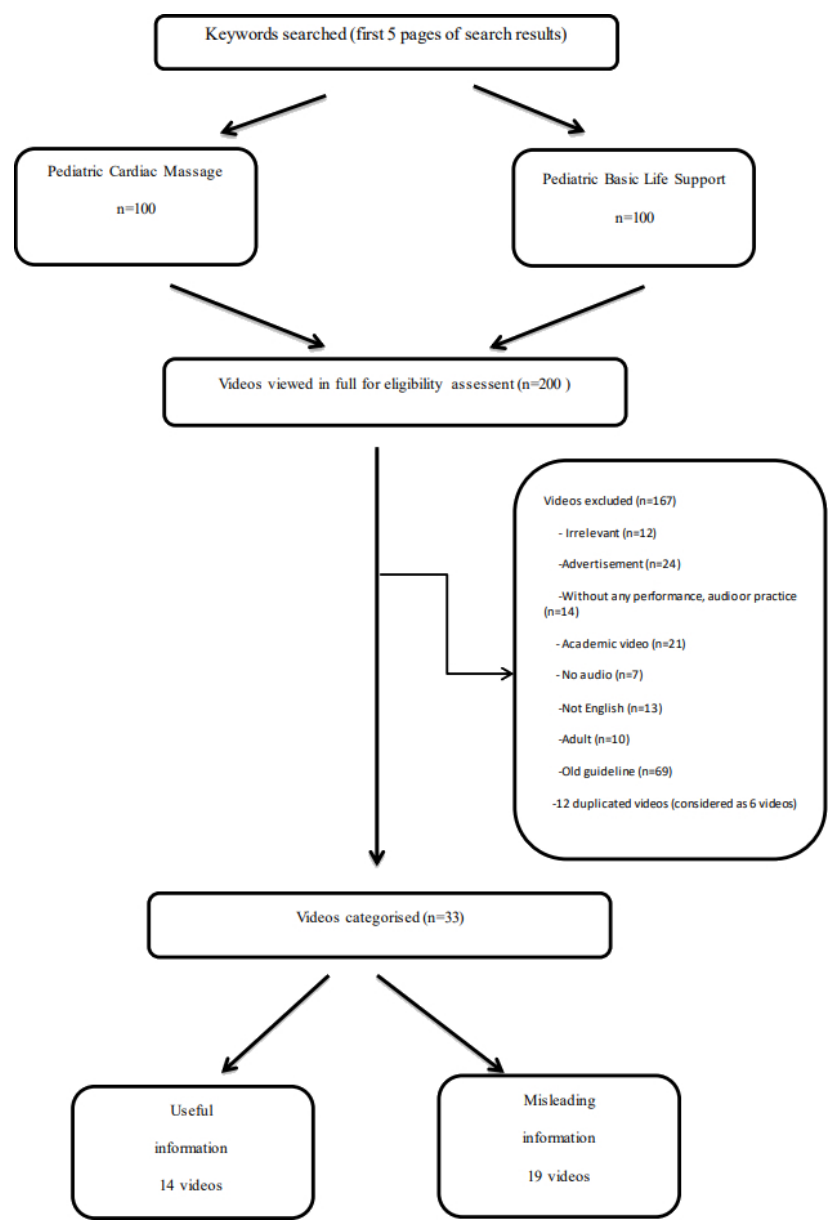

\section{Collection of Data}

Total views, time since upload, daily views, video length (seconds), likes/dislikes received, and uploader characteristics were recorded for each evaluated video. The popularity of videos was assessed using the video power index.

$\mathrm{VPI}=$ Popularity $x$ rating $/ 100$

Popularity $=$ number of likes $\times 100 /$ (like + dislike $)$

Rating $=$ number of views / day 
Table1. Assesing tools of the videos global quality score according to modified Azer criteria

Major criteria
1.Providing scientifically correct information about TYD and CPR.
2.Clear images
3.Idendification of the upload source
4.Clear explanation of the issue
5.Clear sound and no background noise
Minor criteria
1.The video covers the topic identified in the title.
2.Designed at the level of undergraduate medical science
students.
3.The time to download is reasonable.
4.Information about the video uploader is up-to-date.
5.The educational objectives are stated.
6.Demonstrating the CPR or BLS procedure on a human instead of
illustration.

\section{Uploader Characteristics}

The videos were divided into four categories according to their uploaders: Personal uploads (1), private education companies and foundations (2), hospitals (3), and national health services and universities (4). (Table 4)

Table 4. UK Total points of videos

\begin{tabular}{|c|c|c|}
\hline \multirow[b]{2}{*}{ Characteristic } & \multicolumn{2}{|c|}{ UK Total Point } \\
\hline & $R$ value & $P$ value \\
\hline Total view & 0.377 & 0.031 \\
\hline Video length, second & 0.257 & 0.149 \\
\hline $\begin{array}{l}\text { Duration on YouTube } \\
\text { (month) }\end{array}$ & 0.159 & 0.378 \\
\hline Views per day & 0.388 & 0.026 \\
\hline $\begin{array}{l}\text { Video Power Index } \\
\text { (VPI) }\end{array}$ & 0.366 & 0.036 \\
\hline $\begin{array}{l}\text { Comprehensiveness } \\
\text { score }\end{array}$ & 0.384 & 0.027 \\
\hline
\end{tabular}

Evaluation of Up-to-dateness and Accuracy in Terms of Video Content

All videos were evaluated by two independent anesthetists for information accuracy, up-to-dateness, and content (using a 10-point measure including the CPR stages) according to the 2015 AHA guidelines (Table 2). In case of a difference of opinion, a third anesthetist was consulted to reach a consensus.

Table 2. Assesment of the videos according to content and up-to dateness

\section{Evaluation of the Information Accuracy of the Videos}

Accurate Information: Includes all phases related to CPR; up-todate, accurate and learning-helpful videos.

Misinformation: Contains misleading information about CPR (eg, insufficient compression depth and frequency

\section{Relevance:}

Current videos: Prepared according to the 2015 AHA guidelines

Older videos: Prepared according to pre-2015 AHA guidelines

\section{Evaluation of the content (1p Each)}

Consciousness assessment

Respiratuary evaluation

Circulation assesment

Head tilt, chin lift maneuver

Calling for help

CPR to correct area

Adequate compression depth

Correct number of compressions

30:2 for a single person, 15:2 more than one person

Mention of AED

Table 5. General features of videos

\begin{tabular}{|c|c|c|c|c|}
\hline & All videos $(n=33)$ & Useful Information $(n=14)$ & $\begin{array}{l}\text { Misleading Information } \\
(n=19)\end{array}$ & $\mathbf{p}$ \\
\hline Total view & $15685(1021-71362)$ & $38307(9068-76646)$ & $3456(228-28991)$ & 0.038 \\
\hline Video length, second & $307(182-567)$ & $307(206-576)$ & $218(146-567)$ & 0.308 \\
\hline Duration on YouTube (month) & $18.00(12.00-34.00)$ & $16.00(13.00-40.00)$ & $18.00(8.00-34.00)$ & 0.715 \\
\hline Views per day & $13.17(2.84-99.19)$ & $53.69(8.31-121.04)$ & $6.40(.78-30.26)$ & 0.035 \\
\hline Video Power Index (VPI) & $10000(1000-47289)$ & $38758(8200-56680)$ & $2800(200-14800)$ & 0.023 \\
\hline GQS score & $3 \pm 1$ & $4(4-4)$ & $3(2-4)$ & 0.026 \\
\hline Reliability score & $3.55 \pm 1.12$ & $4.00(4.00-5.00)$ & $3.00(2.00-4,00)$ & 0.028 \\
\hline Comprehensiveness score & $70.40 \pm 18.15$ & $76.92(61.54-84,62)$ & $61.54(53.85-92.31)$ & 0.108 \\
\hline UK total point & $11.24 \pm 3.09$ & $14.00(13.00-15.00)$ & $9.00(8.00-11.00)$ & $<0.001$ \\
\hline
\end{tabular}


Figure 2. Criteria used of evaluation of the video contents

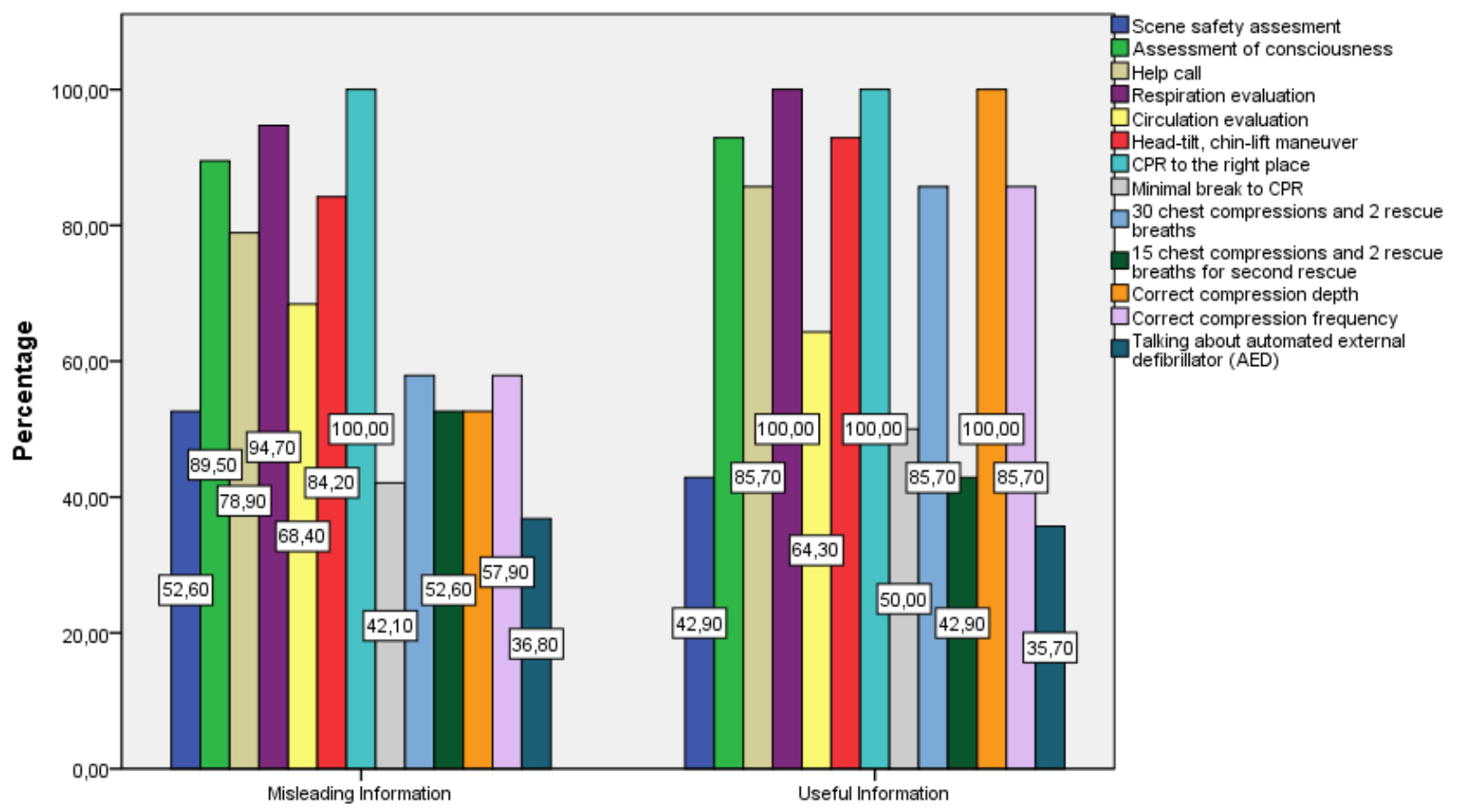

Tablo 3. Sources of uploads among CPR and BLS education videos

\begin{tabular}{|c|c|c|c|c|}
\hline & \multicolumn{4}{|c|}{ Source of uploads } \\
\hline & & $\begin{array}{l}\text { Private } \\
\text { instution }\end{array}$ & Hospital & Individuals \\
\hline \multirow[t]{3}{*}{ All videos } & 10 (100\%) & 9 (100\%) & 7 (100\%) & 7 (100\%) \\
\hline & la (10\%) & $\begin{array}{l}5 a, b \\
(55,6 \%)\end{array}$ & $\begin{array}{l}6 \mathrm{~b} \\
(85,7 \%)\end{array}$ & $2 a, b(28,6 \%)$ \\
\hline & $9 a(90 \%)$ & $\begin{array}{l}4 a, b \\
(44,4 \%)\end{array}$ & $\begin{array}{l}1 \mathrm{~b} \\
(14,3 \%)\end{array}$ & $5 a, b(71,4 \%)$ \\
\hline$p$ value & 0,013 & & & \\
\hline
\end{tabular}

\section{Statistical Analysis}

IBM-Statistical Package for Social Sciences (IBMSPSS Inc.,Chicago, IL, USA) 22.0 program was used for data analysis. 'Shapiro-Wilk test' was used to check whether the data were normally distributed. Continuous variables were expressed as mean and standard deviation or median (interquartile range) depending on whether the variables were normally distributed or not, and categorical variables were expressed as numbers and percentages. Continuous variables were analyzed with the 'independent samples t-test' for normally distributed variables. 'Mann-Whitney U test' was used for analyzing nonnormally distributed continuous variables. Pearson and Spearman correlation analysis was used to investigate the relationship between total video score and basic video features. Inter-rater agreement was calculated with the Cohen's Kappa score. $\mathrm{p}<0.05$ was accepted as statistically significant in all analyses.

\section{Results}

The keywords "pediatric cardiac massage" and "pediatric basic life support" were used on Youtube to search for videos and the first five pages of listed results were included in the evaluation. Accordingly, a total of 200 videos were included in the research, 100 videos for each keyword. 167 videos were excluded from the research based on the exclusion criteria. Of these, 12 were irrelevant, 24 contained advertisements, 21 did not contain any sound or performance, 21 were academic videos, 12 were not in English, 10 contained information on adult CPR or BLS, 55 were prepared according to the outdated guideline, and 12 videos were duplicates. As a result, 33 videos were included in the evaluation. Of these, 14 were categorized as useful and 19 were categorized as misleading.

The average number of views for the videos included in the present research was 15.685 (1.021-71.362). Average video length was 307 seconds (182-567). On average, the videos were uploaded on YouTube for 18 months (12-34). Average daily views was 13.17 (2.84-99.19). According to these statistics, the mean VPI was found to be 10.000 (1.000-47.289), the mean Global quality score was $3 \pm 1$, and the mean reliability score was $3.55 \pm 1.12$. The videos with useful information were compared to the videos that were categorized as misleading. Accordingly, total watch time [38.307 (9.068-76.646)-3.456 (228-28.991)], daily views [53.69 (8.31-121.04)-6.40 (78-30.26)], video power index [38.758 (8.200-56.680)-2.800 (200-14.800)], global quality scores [4 (4-4)-3 (2-4)], accuracy score [4.00 
(4.00-5.00)] )-3 (2.00-4.00)] and UK total score [14.00 (13.00-15.00)-9.0 (8.0-11.0)] were significantly higher in useful videos compared to misleading videos $(p<$ 0.05). However, there is no significant difference found between the groups in terms of video length and time after videos were uploaded to YouTube $(p>0.05)$. (Table 5)

Video contents were evaluated in terms of mentioning key topics including environment safety, evaluation of consciousness, calling for help, respiratory evaluation, evaluation of circulation, performing the head-backchin-up maneuver, performing CPR on the right location, minimum interruption to CPR, 30:2 ratio for single rescuer and 15:2 ratio for double rescuer, correct compression depth and frequency, and use of automatic external defibrillator (AED). No statistically significant difference was found between the groups in terms of these topics (Figure 2).

Inter-rater agreement for total scores for Pediatric CPR and Pediatric basic life support videos was evaluated with the Cohen's kappa statistic. Cohen's kappa value was 0.756, indicating a strong inter-rater agreement (95\% Cl: 0.531-0.981). Videos categorized as educationally useful and misleading were compared according to uploader characteristics. It was found that useful videos were mostly uploaded by hospitals, while misleading videos were mostly uploaded by universities or Local Health Institutions. A statistically significant difference was found between useful and misleading videos in terms of uploader characteristics ( $p=0.013$ ) (Table 3).

A significant correlation was found between total video score and total views, daily views, video power index and comprehensiveness score $(r=0.377, p=0.031$; $r=0.388, p=0.026 ; r=0.366, p=0.036$; respectively). No significant correlation was found between total video score and video length and time passed after video was uploaded to YouTube. $(r=0.257, p=0.149 ; r=0.159$, $\mathrm{p}=0.378$; respectively) (Table 4 ).

\section{Discussion}

In the present research, English videos on 'pediatric CPR' and 'Basic Life Support' uploaded on YouTube were evaluated in terms of whether they complied with new guidelines, provided correct and accurate information, and whether they were educationally useful or misleading. Based on the evaluations, it was found that only $16.5 \%$ of the videos were suitable to be included in the study. Despite the keyword search, 83.5\% of the videos were excluded from the study. Exclusion rate was previously found as between $80 \%$ and $94 \%$ in various studies $(9,11,16,17)$. The fact that the majority of the search results were excluded from the study indicates that most videos are uploaded with tags unrelated to the video content. Furthermore, some videos are uploaded solely for advertisement purposes. In addition, videos prepared according to outdated guidelines are still available on YouTube.
This may limit the access of viewers to up-to-date information on pediatric CPR and BLS on YouTube, and increase the likelihood that irrelevant and/or misleading videos are accessed.

In a previous study, Beydilli et al. found that $33.3 \%$ of the videos pediatric CPR and BLS were useful. In this study, compliance with current guidelines was taken as the criterion of usefulness. In another study, Azer SA et al. examined videos on cardiovascular and respiratory examination and reported that $28 \%$ of the videos were educationally useful(17). Azer SA et al. conducted another study on nervous system examination, and reported that $47 \%$ of the videos were useful (20). In the present research, $42 \%$ (14) of the videos were found useful. However, when all 300 videos listed on the top five pages were evaluated, it was found that only $7 \%$ of the videos were useful. This result suggests that the educational level of the evaluated videos on YouTube is insufficient.

The biggest problem with open platforms such as YouTube is that account authentication cannot be performed and people can anonymously upload videos on virtually any subject. In the present research, it was found that $21 \%$ of the videos on pediatric CPR and BLS were uploaded by individuals. In the study of Beydilli et al., this rate was $34 \%$. In another study, Murugiah et al. reported that half of the videos examined were uploaded by unauthenticated individuals. Although information can be disseminated quickly through YouTube, the absence of control mechanisms for uploading videos allows anyone to upload videos on any subject, including medical issues. Platform likes YouTube have initially been used for entertainment purposes, but now they have gained traction as learning platforms as well. Therefore, allowing people to easily upload videos to these platforms without any control can increase the risk of rapid dissemination of erroneous information.

While educationally useful videos were mostly uploaded by hospitals, unhelpful or misleading videos were mostly uploaded by universities, national health institutions, and individuals. In their study, Azer SA et al. also reported similar findings(1). This clearly demonstrates that health professionals should take more initiative in disseminating useful information.

Total views, daily views, video power index, reliability scores and global quality scores of the videos categorized as useful according to Azer SA criteria were higher compared to misleading videos. This result demonstrates that useful videos attract more attention from viewers. In terms of content, it was determined that basic CPR steps such as environment safety, evaluation of consciousness, evaluation of respiration and circulation, calling for help, headback-chin-up maneuver, and performing CPR on the right location were mentioned almost equally in both groups. This shows that viewers value educational quality more than content. Current information, such 
as compression depth and correct CPR frequency, is mentioned more commonly in useful videos, albeit not sufficiently. Automated external defibrillator was mentioned in the 2015 AHA guidelines. In the videos evaluated in both groups, automated external defibrillator was mentioned in only $35 \%$ of the videos. In the study of Elicabuk et al., AED was mentioned in 14\% of the videos evaluated. Minimal interruption to CPR was mentioned in only $50 \%$ of the videos and this ratio was low. When the groups were compared in terms of all content parameters, there was no statistically significant difference between the groups. In light of the above-mentioned results, it can be the concluded that the AHA current guideline is ignored on most of the videos on YouTube. Furthermore, content alone is not a healthy criterion for video quality and usefulness. Therefore, we recommend that Azer criteria should be taken into account when creating videos for YouTube and video content should be prepared in accordance with the current guidelines.

There are certain limitations of this study. The most important limiting factor was that the study was evaluated according to previous guideline rather than the current October, 2020 AHA guideline. Videos uploaded to portals other than YouTube were not evaluated and non-English videos were not included the study. Another limitation was that the scores for "reliability, GQS, and UK usefulness" were calculated subjectively.

\section{Conclusion}

Based on the results of the present research, it can be concluded that it is quite difficult to access videos directly related to CPR on YouTube. Furthermore, most videos related to CPR were prepared according to outdated guidelines. Useful videos received more likes and views, but no significant difference was found between the videos in terms of content. These factors limit the use of YouTube for pediatric CPR training and informational purposes. Correct and high-quality CPR significantly increase the chance of survival. Therefore, we recommend that YouTube videos on pediatric CPR should be prepared in accordance with current guidelines, UK usefulness criteria should be taken into account to increase views and likes, and a YouTube Health section should be created for easy access to videos directly related to pediatric CPR.

\section{Financial support:}

No financial support was used in the study.

\section{Conflict of interest:}

There is no conflict of interest between the authors.

\section{References}

1.Azer SA. Understanding pharmacokinetics: are YouTube videos a useful learning resource? European review for medical and pharmacological sciences. 2014;18(13):1957-67.

2.Sutherland S, Jalali A. Social media as an open-learning resource in medical education: current perspectives. Advances in medical education and practice. 2017:8:369-75.

3.Pearson D, Bond MC, Kegg J, Pillow T, Hopson L, Cooney R, et al. Evaluation of Social Media Use by Emergency Medicine Residents and Faculty. West J Emerg Med. 2015;16(5):715-20.

4.Eysenbach G, Köhler C. Health-related searches on the Internet. Jama. 2004;291 (24):2946.

5.Basnet B, Bhandari R, Moore M. Initial resuscitation for Australasian Triage Scale 2 patients in a Nepalese emergency department. Emergency medicine Australasia : EMA. 2012;24(4):430-4.

6.Lee DH, Kim CW, Kim SE, Lee SJ. Use of step stool during resuscitation improved the quality of chest compression in simulated resuscitation. Emergency medicine Australasia : EMA. 2012;24(4):369-73.

7.Sekimoto $M$, Noguchi $Y$, Rahman M, Hira K, Fukui M, Enzan K, et al. Estimating the effect of bystander-initiated cardiopulmonary resuscitation in Japan. Resuscitation. 2001;50(2):153-60.

8.Liu KY, Haukoos JS, Sasson C. Availability and quality of cardiopulmonary resuscitation information for Spanish-speaking population on the Internet. Resuscitation. 2014;85(1):131-7.

9.Murugiah K, Vallakati A, Rajput K, Sood A, Challa NR. YouTube as a source of information on cardiopulmonary resuscitation. Resuscitation. $2011 ; 82(3): 332-4$.

10.Tutar MS, Emre E, Hanedan B, Hanedan B. Evaluation of YouTubebased 'Basic Life Support' and 'Cardiopulmonary Resuscitation'Videos in Turkish. DÜSTAD Dünya Sağlık ve Tabiat Bilimleri Dergisi.2021 (1):68-87.

11.Yaylaci S, Serinken M, Eken C, Karcioglu O, Yilmaz A, Elicabuk H et al. Are YouTube videos accurate and reliable on basic life suppor and cardiopulmonary resuscitation? Emergency medicine Australasia : EMA. 2014;26(5):474-7.

12.Beydilli H, Serinken M, Eken C, Elicabuk H, Dal O, Acar E, et al. The validity of YouTube videos on pediatric BLS and CPR. Telemedicine and e-Health. 2016;22(2):165-9.

13.Azer SA, AIGrain HA, AlKhelaif RA, AlEshaiwi SM. Evaluation of the Educational Value of YouTube Videos About Physical Examination of the Cardiovascular and Respiratory Systems. Journal of medical Internet research. 2013;15(11):e241.

14.Azer SA. Can "YouTube" help students in learning surface anatomy? Surgical and Radiologic Anatomy. 2012;34(5):465-8.

15.Azer SA, AIEshaiwi SM, AIGrain HA, AIKhelaif RA. Nervous system examination on YouTube. BMC Medical Education. 2012;12(1):126.

16. Elicabuk H, Yaylacı S, Yilmaz A, Hatipoglu C, Kaya FG, Serinken M. The Reliability of Turkish "Basic Life Support" and "Cardiac Massage" Videos Uploaded to Websites. Eurasian J Med. 2016;48(1):15-9.

17. Saşmaz MI, Akça AH. Reliability of trauma management videos on YouTube and their compliance with ATLS(®) (9th edition) guideline. European journal of trauma and emergency surgery : official publication of the European Trauma Society. 2018;44(5):753-7. 